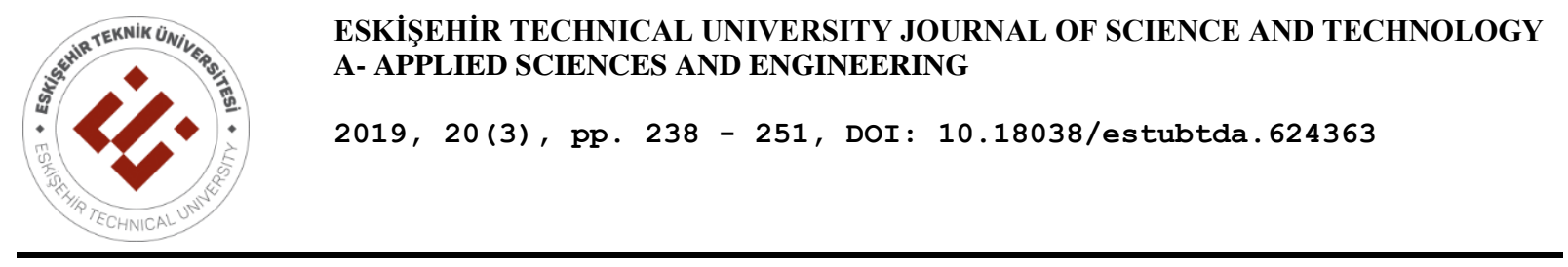

\title{
APPLICABILITY OF TIME-DEPENDENT SEISMICITY MODEL FOR EARTHQUAKE OCCURRENCE ALONG THE NORTH ANATOLIAN FAULT ZONE
}

\author{
Nilgün SAYIL ${ }^{1, *}$ \\ ${ }^{1}$ Department of Geophysics Engineering, Engineering Faculty, Karadeniz Technical University, Trabzon, Turkey
}

\begin{abstract}
The applicability of the time-dependent seismicity model was investigated for earthquakes occurrence along the North Anatolian Fault Zone. This region was separated into thirteen seismogenic zones by virtue of specific seismological and geomorphological criteria, and RTIMAP (regional time and magnitude predictable) model was applied for these zones. The data including in both instrumental period $(M s \geq 5.5)$ until the beginning of 2016 and historical period ( $I o \geq 9.0$ corresponding to $M s \geq 7.0$ ) before 1900 have been used in the study. Interevent times and magnitudes of mainshocks generated in each zone have predictive properties expressed by the RTIMAP. For the region considered, the relationship with increasing slope between the time interval of the events and the magnitude of the preceding earthquake shows that this model is suitable. On the basis of these equations and taking into account the formation time and magnitude of the last events in each zone, probabilities to the next main shocks in five decades and the magnitudes of the next events were estimated.
\end{abstract}

Keywords: North Anatolian Fault Zone, Time-dependent Seismicity, RTIMAP, Earthquake Occurrence Probability

\section{INTRODUCTION}

Most seismic hazard studies are based on time-independent models [1-4]. These models are based on the Gutenberg-Richter formula for the magnitude distribution of the Poisson distribution for time. Researchers looked for a time-dependent model of seismicity to meet the constraints and shortcomings of independent models and developed various approaches to assess these models [5-11]. These approaches indicate that the time of repetition for earthquakes occurring at the edge of a fault supports time predictive models.

In the time-predictable model, the time interval between two large earthquakes is proportional to the slip amount of the preceding earthquake and a large earthquake occurs when the stress has reached a limit value. The magnitude-predictable model describes the relationship between the magnitude of the events before and after and evidences that the larger the magnitude of the preceding mainshock, the smaller the magnitude of the following mainshock. Therefore, the time-predictable and magnitudepredictable models were represented as RTIMAP (regional time and magnitude predictable) model, which applies to seismogenic zones with main fault and other smaller ones [12]. Several scientists have applied this model [11, 13-19] at different seismogenic regions of world. In this paper, we are testing the validity of the time-dependent seismicity model for earthquake generation along the North Anatolian Fault Zone (NAFZ) bounded by $38.5^{\circ}-41.5^{\circ} \mathrm{N}$ and $26.0^{\circ}-43.5^{\circ} \mathrm{E}$.

\section{SEISMOTECTONIC OF THE REGION}

The northern boundary of the Anatolian Plate is the Anatolian Trough and the right-lateral, strike-slip North Anatolia Fault Zone (NAFZ). The southern boundary of the Anatolian Plate is formed by the Hellenic Arc, south of Cyprus, and the East Anatolia Fault Zone (EAFZ), which joins the North East Anatolia Fault Zone (NEAFZ) at Karliova Junction (KJ) [20-22].

*Corresponding Author: sayil@ktu.edu.tr

Received: 01.11.2018 Published: 26.09.2019 


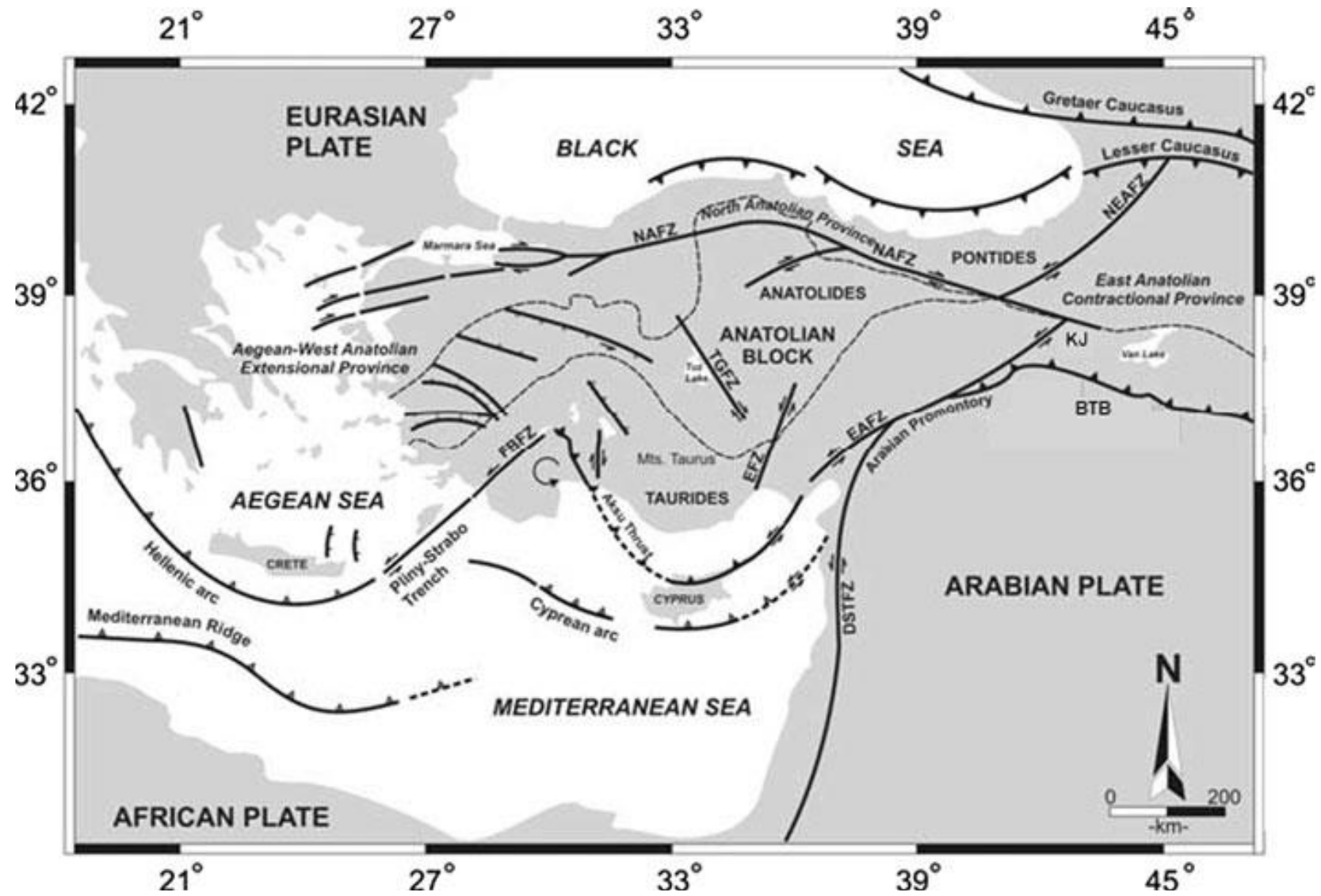

Figure 1. Plate tectonics model of Anatolia and surrounding area (The Institute of Mineral Research and Exploration, Ankara, Turkey)

The North Anatolian fault intersects the East Anatolian fault in the east (Figure 1). In general, while the eastern part of the fault has being compressed, its western part is under tension. Thus earthquake recurrence intervals vary in wide range depending on these regimes. In Western Anatolia, NAFZ passes through the Marmara Sea and continues the collapse of the North Aegean [23].

Main segments from east to the west of NAFZ are the Erzincan segment of $350 \mathrm{~km}$ long (ruptured in 1939), the Ladik-Tosya segment of $260 \mathrm{~km}$ (ruptured in 1943), the Gerede segment of $180 \mathrm{~km}$ (ruptured in 1944) and the Saros segment of longer than $100 \mathrm{~km}$ (ruptured in 1912). The other segments are located at the eastern end (Varto segment, ruptured in 1966) and on the branches to the west (Mudurnu Valley segment ruptured in 1957 and 1967). The southern strand is called İznikMekece (İznik-Mekece segment unbroken in the past century, Manyas segment ruptured in 1964, Yenice-Gönen segment ruptured in 1953) and the northern strand is called Sapanca-İzmit (Sapancaİzmit and Düzce segments ruptured in 1999). Furthermore, the main regions contain some sub regions toward the both directions. In this study, main and other segments of NAFZ are considered in the creation of seismogenic zones (Figure 2). 


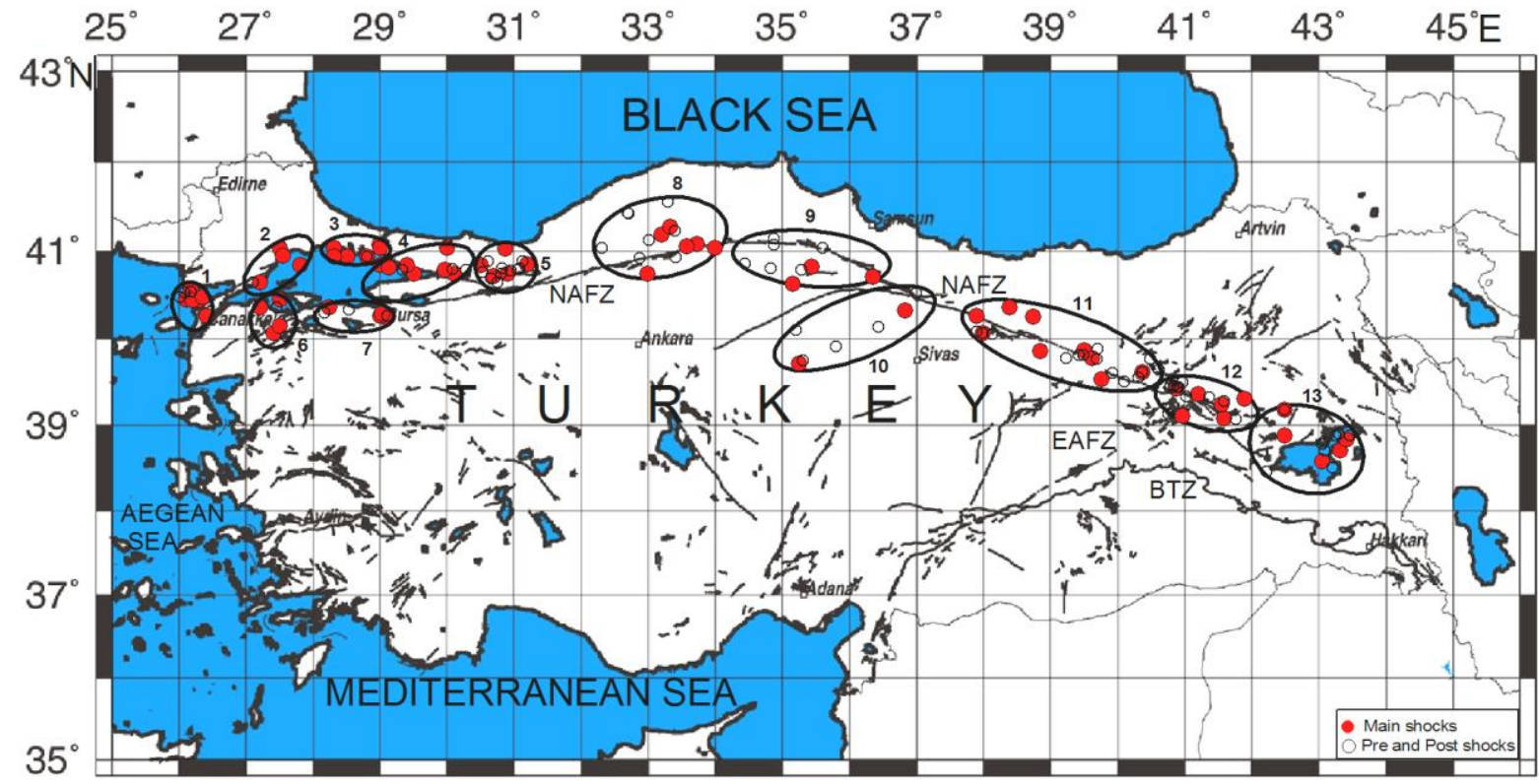

Figure 2. Tectonic and seismicity map of the North Anatolian Fault Zone and thirteen seismogenic zones. Dark and light colored circles represent shallow main shocks and previous- or after main shocks, respectively.

\section{THE APPLICABILITY OF THE RTIMAP MODEL IN THE NAFZ}

From historical and instrumental seismological data and geological observations, it can be observed that strong $(M s \geq 6.0)$ and large $(M s \geq 7.0)$ earthquakes are generated in certain seismogenic zones and follow relations of the RTIMAP model [18].

The instrumental $\left(M_{S} \geq 5.5\right)$ up to end of 2015 and historical data $\left(I_{0} \geq 9.0\right.$ corresponding to $\left.M_{S} \geq 7.0\right)$ before 1900 (sources given in [24]) have been used in the analysis. Magnitudes in this catalogue are presented in different scales $\left(M s, m_{b}, M_{w}, M_{L}\right.$ and $\left.M_{d}\right)$. Since the magnitude must be homogeneous, all magnitudes were transformed surface wave magnitude $\left(M_{S}\right)$ through a set of empirical equations derived based on regional earthquakes (Figure 3). All calculated relationships are consistent with those previously determined [25-28]. Likewise, the experimental scaling relation between surface wave magnitude and intensity, $M s-I_{0}$, estimated by [29] for study area were used. Another important criterion for the analysis is completeness of the data. In this study, the catalog completeness was tested by the method recommended by [30], the smallest magnitude has been chosen as $M_{c}=5.5$ for instrumental period and $M_{c}=7.0$ for historical period in all seismogenic zones.

RTIMAP model of the seismicity proposed by [6] and its modified form by [12] is given by the Equations (1) and (2):

$$
\begin{aligned}
\log T_{t} & =b M_{\text {min }}+c M_{p}+d \log M_{0}+q \\
M_{f} & =B M_{\text {min }}+C M_{p}+D \log M_{0}+m
\end{aligned}
$$

Where $b, c, d, q, B, C, D, m$ are constants to be calculated. $M_{f}$ and $M_{p}$ are the magnitudes of the subsequent and previous events, respectively, $T_{t}$ is the interevent time measured in years and $M_{0}$ is the annual seismic moment rate in the source. The steps of the process are definition of the zones, calculation of the seismic moment, declustering of the catalogue, definition of the constants of 
Equations (1), (2) and finally determination of magnitudes, repetition times and probabilities of the next events.
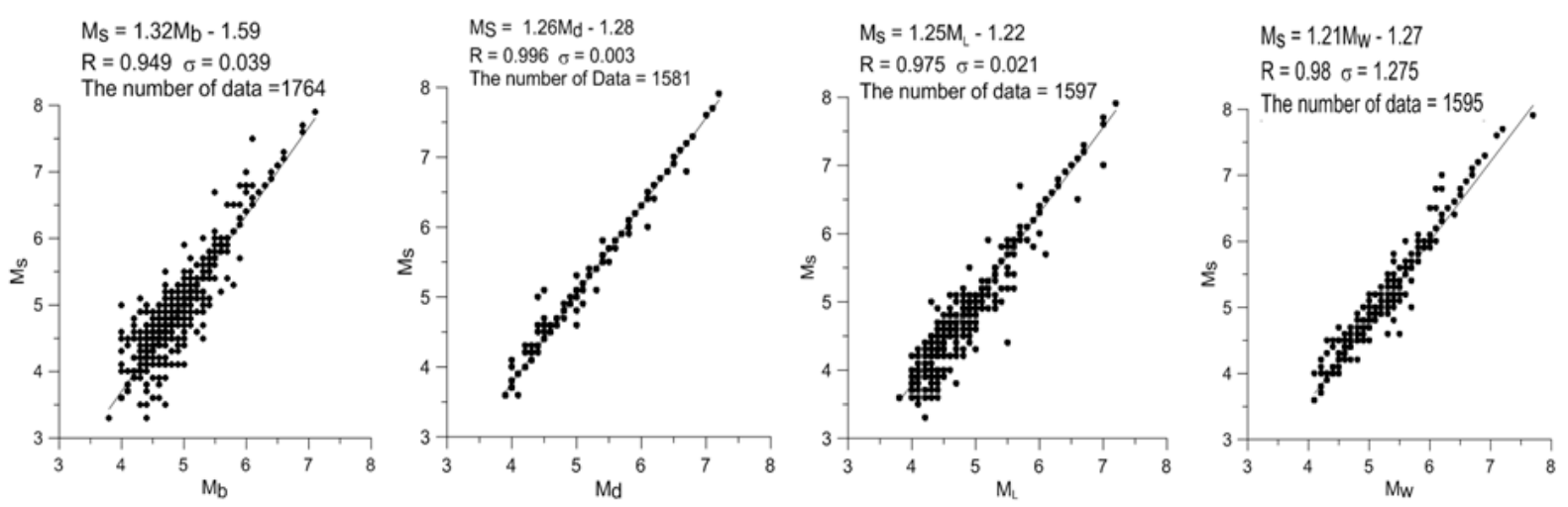

Figure 3. Correlations of $M_{S}-m_{b}, M_{w}, M_{L}$ and $M_{d}$ used in this study. $\sigma$ and $R$ shows standard deviation and correlation coefficient, respectively.

The first step for the implementation of the method is selection of seismogenic zones. Many seismotectonic and geomorphological properties like the distribution of the events, seismicity, the largest magnitude earthquake, kind of fault, the effects of earthquakes on each other, region anotmy, size of the fracture associated with the magnitude of the earthquake should be taken into account in the creation of seismogenic zones [31]. Each source may include the main fault of the largest event $(M s \geq$ 7.0), and even other faults which consists of smaller events. The earthquakes in each zone don't have to occur with the same fault but they must have the same tectonic character.

In this study, thirteen seismogenic zones have been selected by taking into account the aboveidentified criteria and the base and side segments of the NAFZ described in Section 2; Seismogenic zone 1 includes Saros Bay which located on the north branch of NAFZ. The fault plane solutions of the earthquakes around the Saros Gulf clearly indicate right-lateral movement. The largest earthquake of Saros Bay is occurred in $1875\left(M_{S}=7.0\right)$. Seismogenic zone 2 contains Tekirdag basin which is take place in the western Sea of Marmara. A right-lateral strike-slip stress regime is enabled in Tekirdag basin. The largest events in this seismogenic zone are occurred in Murefte $\left(M_{S}=7.4\right.$, in 1912 ) and northern edges of Central basin $\left(M_{S}=7.7\right.$, in 1766). Seismogenic zone 3 (Istanbul) includes Central basin of Marmara Sea. A right-lateral strike-slip stress regime is dominant in Central Basin of Marmara Sea [23]. The largest event in this seismogenic zone is happened in $447\left(M_{S}=7.5\right)$. Seismogenic zone 4 contains Cinarcik basin which is take place in the eastern Sea of Marmara. A strike-slip type mechanism is dominant in Northwest part of Cinarcik basin, but a normal-faulting mechanism is dominant in its central part. The largest event in this zone is occurred in İzmit $\left(M_{S}=7.8\right.$, in 1999).

Seismogenic zone 5 includes the right-lateral strike-slip Düzce fault which advancing from the southern branch of the NAFZ. The largest event in this zone is occurred in Düzce $\left(M_{S}=7.5\right.$, in 1999). Seismogenic zone 6 contains Yenice-Gonen fault which is releated to right-lateral strike-slip fault mechanism. The largest event in this seismogenic zone is occurred in $1953\left(M_{S}=7.5\right)$. Seismogenic zone 7 includes Gemlik Bay, Bursa fault and Uluabat fault situated in South branch of NAFZ. The right lateral strike-slip movement is enabled to the NE-SW oriented Uluabat fault. The largest event in this zone is occurred in $1855\left(M_{S}=7.5\right)$.

Seismogenic zone 8 contains three large intramountain basins (Tosya, Ilgaz, and Cerkes). Thrust faults length are about $30 \mathrm{~km}$ and have an average strike consistent with the dextral slip on the NAFZ. The largest events in this zone are happened in Ilgaz basin $\left(M_{S}=7.2\right.$, in 1943) and Cerkes basin $\left(M_{S}=7.2\right.$, 
in 1944). Seismogenic zone 9 includes Havza-Ladik basin. The largest event in this zone is occurred in $1942\left(M_{S}=7.0\right)$. Seismogenic zone 10 includes Erbaa basin. The Erbaa pull-apart basin is a discontinuity along the fault [32]. The largest event in this zone is occurred in $1916\left(M_{S}=7.1\right)$.

Seismogenic zone 11 includes the NW-SE striking Erzincan basin which appears to be a major step over along the NAFZ [33]. The largest events in this seismogenic zone are occurred in $1938\left(M_{S}=7.9\right)$ and in $1949\left(M_{S}=7.0\right)$. Seismogenic zone 12 includes the Karlova Triple Junction which is releated to the continental collision between the Arabian and Eurasian Plates. The largest event in this zone is occurred in $1966\left(M_{S}=7.0\right)$. Seismogenic zone 13 contains Van fault, Tutak fault and Kalecik fault. Interrelated effects between the Arabian and Eurasian plates naturally created several strike-slip and fewer thrust fault. The largest event in this zone is occurred in $2011\left(M_{S}=7.4\right)$.

The second step in practicing the method is calculation of the seismic moment $\left(M_{0}\right)$ for each zone [34]. $M_{\max }$ were found by taking into account the data available for each zone. $a$ and $b^{\prime}$ constants in the classical relation of [35] are normalized for one year for each seismogenic zone. $b^{\prime}=0.7(\sigma=0.03)$ for six zones and $b^{\prime}=0.9(\sigma=0.02)$ for seven zones were determined. The computed values of parameters $a, b^{\prime}, M_{\max }$ and $\log \dot{M}_{0}$ for each zone are shown in Table 1 .

Table 1. Fundamental parameters for each zone. $a$ and $b^{\prime}$ are constants of Gutenberg-Richter relation, $\mathrm{M}_{\max }$; the biggest magnitude and $\log \dot{\mathrm{M}}_{0}$; the logarithm of the moment rate.

\begin{tabular}{llcccc}
\hline Seismogenic Zones & $\boldsymbol{a}$ & $\boldsymbol{b}^{\prime}$ & $\boldsymbol{M}_{\max }$ & $\boldsymbol{\operatorname { l o g } \dot { M } \boldsymbol { 0 }}$ \\
\hline 1 Saros Gulf & 2.94 & 0.7 & 7.0 & 24.91 \\
2 Tekirdag & 2.82 & 0.7 & 7.7 & 25.35 \\
3 İstanbul & 2.76 & 0.7 & 7.5 & 25.13 \\
4 İzmit & 2.98 & 0.7 & 7.8 & 25.59 \\
5 Düzce & 2.94 & 0.7 & 7.5 & 25.31 \\
6 Bandirma & 4.74 & 0.9 & 7.5 & 25.74 \\
7 Bursa & 3.81 & 0.9 & 7.6 & 24.81 \\
8 Bolu & 5.00 & 0.9 & 7.2 & 25.42 \\
9 Merzifon & 4.00 & 0.9 & 7.0 & 24.70 \\
10 Tokat & 4.00 & 0.9 & 7.1 & 24.76 \\
11 Erzincan & 3.30 & 0.7 & 7.9 & 25.95 \\
12 Karliova & 6.00 & 0.9 & 6.9 & 25.87 \\
13 Van & 5.40 & 0.9 & 7.4 & 25.45 \\
\hline
\end{tabular}

The third step of the method is declustering process. Each complete catalogue is declustered so that the mainshocks to fulfil the condition: Using the earthquakes data, it was shown that the $\sigma / T$ ratio was smaller than 0.50 for $\Delta t \geq 15$ years and remained almost constant $(\sim 0.35)$ with increasing $\Delta t$. where $T$ is the mean return period of the mainshocks of a seismogenic zone and $\sigma$ is its standard deviation, namely, the mainshocks to exhibit a quasi-periodic behavior. The ratio $\sigma / T$ decreases with increasing declustering time-window, $\Delta t$. For $\Delta t \geq 15$ years, this ratio becomes small and remains constant $(\sim 0.30)$ [36]. The relation $\log t_{a}=0.06+0.13 M_{p}$ for postshocks $\left(t_{a}\right)$ activity and as $t_{p}=3$ years for the preshocks $\left(t_{p}\right)$ activity suggested by [31] were used for declustering procedure in this study.

\section{RESULTS}

The earthquake data used for RTIMAP model are illustrated in Table 2; the completeness year for each magnitude, and cut-off magnitude $\left(M_{c}\right)$ in this period, before $(f)$ and after $(a)$ event activities, cumulative magnitude $(M)$ of each series, values of the minimum main shock $\left(M_{\min }\right)$, before $\left(M_{p}\right)$ and after $\left(M_{f}\right)$ main shocks magnitudes, time between consecutive main shocks $\left(T_{t}\right)$, formation time (years) belonging to the consecutive main shocks. 
In order to estimate the parameters of Equation (1), the RTIMAP model suggested by [12] was fitted. The constants $(b, c, d, q, B, C, D$ and $m$ ) of Equations (1) and (2) were determined by multilinear regression technique [37]. Using the 247 observational data $\left(T_{t}, M_{\min }, M_{p}, M_{f}\right)$ (Table 2) and the moment rates $\left(\dot{M}_{0}\right)$ (Table 1), the constants of Equation (1) were determined.

$$
\log T_{t}=0.29 M_{\min }+0.19 M_{p}-0.34 \log \dot{M}_{0}+7.07
$$

The multiple correlation coefficient $(\mathrm{R})$ and standard deviation $(\sigma)$ of Equation (3) are 0.76 and 0.32 , respectively. The relationship with increasing slope between $T_{t}$ and $M_{p}$ means that the RTIMAP method is operable in the examined area. $\log T^{*}$ is determined by the raletion $\log T^{*}=\log T$ $0.29 M_{\min }+0.34 \log \dot{M}_{0}-7.07$ for $M_{p}$ values. The correlation between $\log T^{*}$ and $M_{p}$ is illustrated in Figure 4a, where $T, M_{\min }, \log _{\dot{M}_{0}}$, and $M_{p}$ are actual values. Likewise, the constants of Equation (2) were determined.

$$
M_{f}=0.82 M_{\text {min }}-0.14 M_{p}+0.18 \log \dot{M}_{0}-1.96
$$

$\mathrm{R}$ and $\sigma$ of Equation (4) are 0.66 and 0.43 , respectively. $M_{f}^{*}$ value is determined by the relation $M_{f}^{*}=$ $M_{f}-0.82 M_{\min }-0.18 \log \dot{M}_{0}+1.96$ for each $M_{p}$. The correlation between $M_{f}^{*}$ and $M_{p}$ is illustrated in Figure $4 \mathrm{~b}$. The relationship with decreasing slope between $M_{f}$ to $M_{p}$ means that a large earthquake will follow a small earthquake and vice versa.

(a)

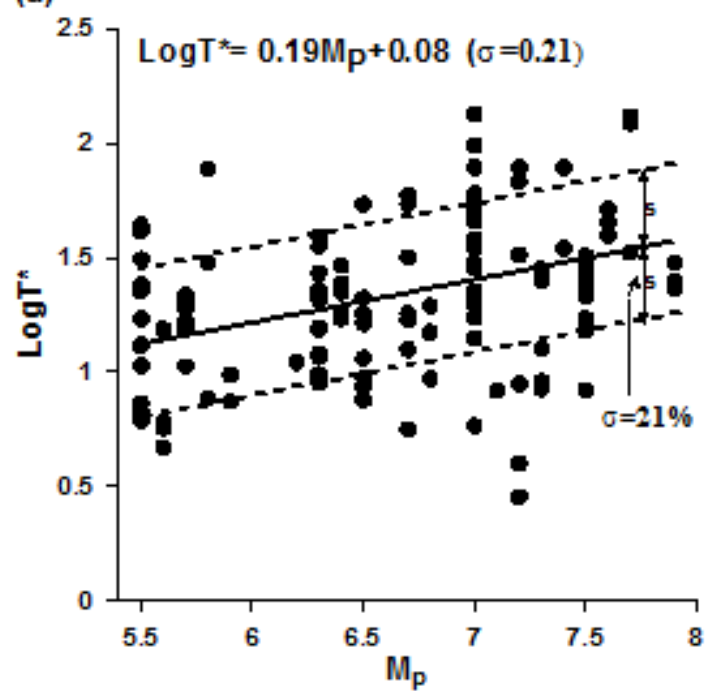

(b)

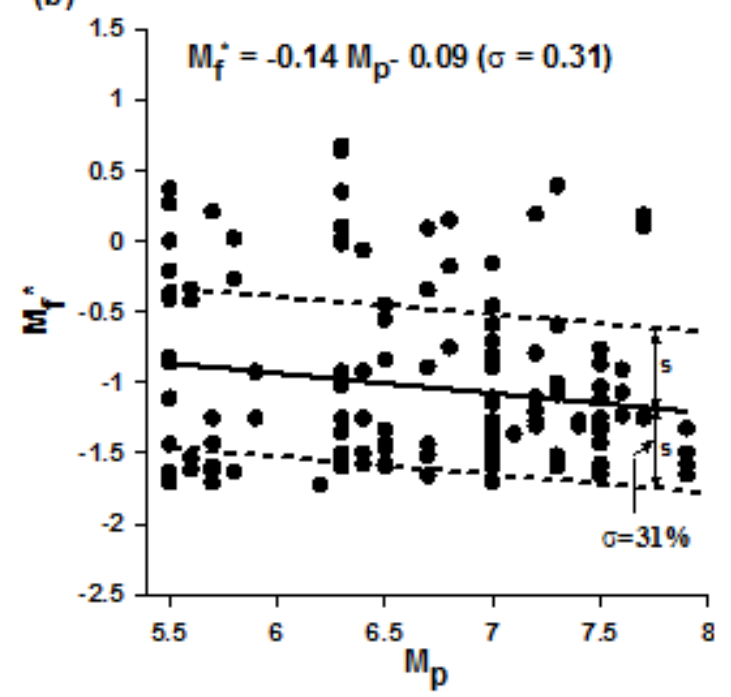

Figure 4 (a) The relationship between $T^{*}$ and $M_{p}$; (b) The relationship between $M_{f}^{*}$ and $M_{p}$. Broken lines show interval bands (s) for estimates of $\sigma=21 \%$ and $\sigma=31 \%$. 
Table 2. Earthquake data used for RTIMAP Model; $a$ : aftershocks, $f$ : foreshocks, $M$ : cumulative magnitude.

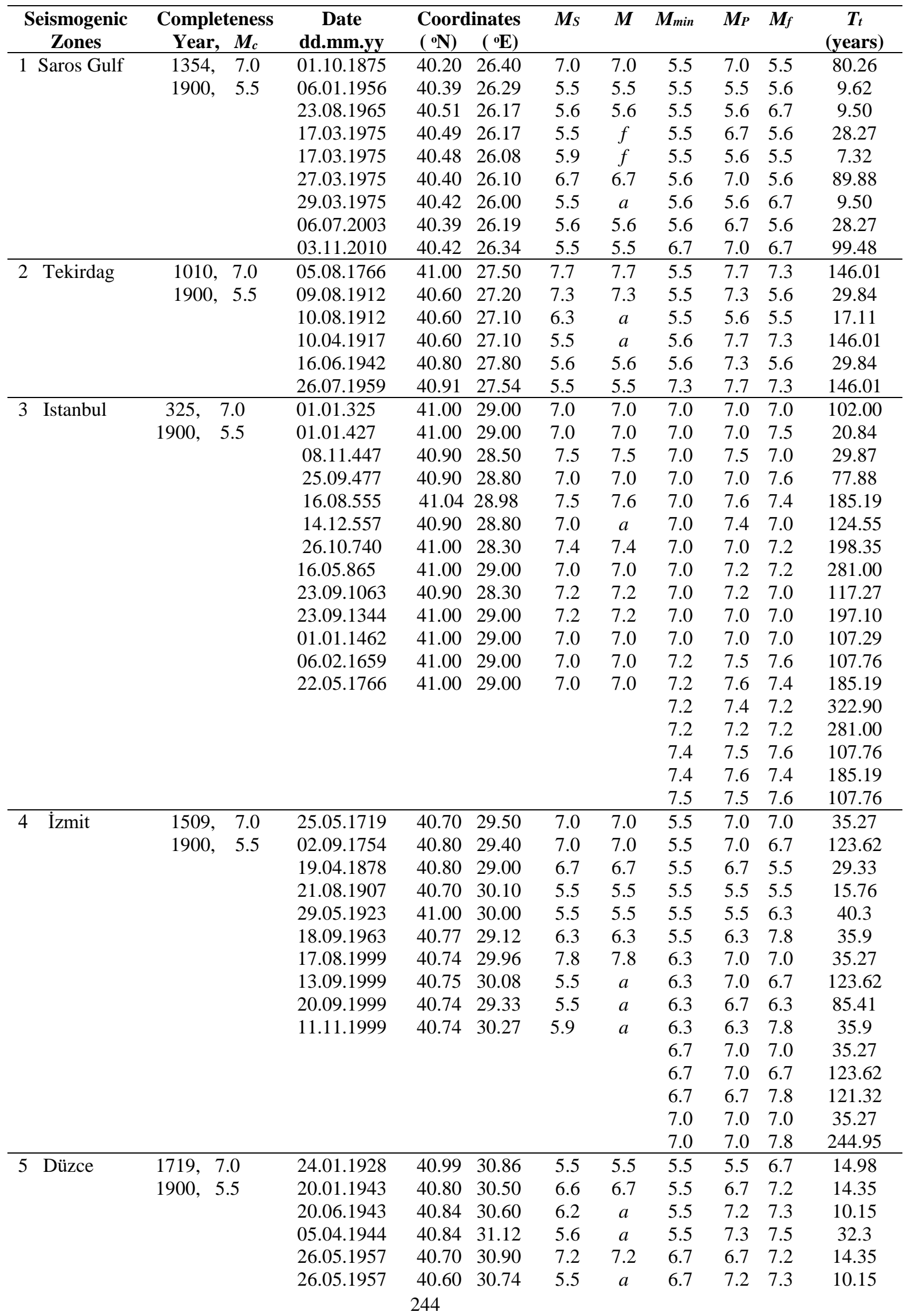


Sayll / Eskişehir Technical Univ. J. of Sci. and Tech. A - Appl. Sci. and Eng. 20 (3) - 2019

\begin{tabular}{|c|c|c|c|c|c|c|c|c|c|c|}
\hline \multirow[t]{9}{*}{ Cont.Table 2} & & 26.05 .1957 & 40.76 & 30.81 & 5.9 & $a$ & 6.7 & 7.3 & 7.5 & 32.3 \\
\hline & & 27.05 .1957 & 40.73 & 30.95 & 5.8 & $a$ & 7.2 & 7.2 & 7.3 & 10.15 \\
\hline & & 22.07 .1967 & 40.67 & 30.69 & 7.3 & 7.3 & 7.2 & 7.3 & 7.5 & 32.3 \\
\hline & & 22.07 .1967 & 40.70 & 30.80 & 5.5 & $a$ & 7.3 & 7.3 & 7.5 & 32.3 \\
\hline & & 30.07 .1967 & 40.72 & 30.52 & 5.6 & $a$ & & & & \\
\hline & & 17.08.1999 & 40.64 & 30.65 & 5.6 & $f$ & & & & \\
\hline & & 06.09.1999 & 40.76 & 31.07 & 5.7 & $f$ & & & & \\
\hline & & 12.11.1999 & 40.81 & 31.19 & 7.5 & 7.5 & & & & \\
\hline & & 12.11.1999 & 40.74 & 31.05 & 5.5 & $a$ & & & & \\
\hline \multirow[t]{6}{*}{6 Bandirma } & $543,7.0$ & 04.01 .1935 & 40.40 & 27.50 & 6.7 & 6.8 & 5.7 & 6.8 & 7.5 & 18.20 \\
\hline & $1900, \quad 5.5$ & 04.01 .1935 & 40.30 & 27.45 & 6.3 & $a$ & 5.7 & 7.5 & 5.7 & 16.04 \\
\hline & & 18.03 .1953 & 40.00 & 27.40 & 7.5 & 7.5 & 5.7 & 5.7 & 6.1 & 14.33 \\
\hline & & 18.03 .1953 & 39.96 & 27.59 & 5.5 & $a$ & 6.1 & 6.8 & 7.5 & 18.20 \\
\hline & & 03.03 .1969 & 40.08 & 27.50 & 5.7 & 5.7 & 6.1 & 7.5 & 6.1 & 30.29 \\
\hline & & 05.07 .1983 & 40.30 & 27.20 & 6.1 & 6.1 & 6.8 & 6.8 & 7.5 & 18.20 \\
\hline \multirow[t]{7}{*}{7 Bursa } & $715,7.0$ & 28.02 .1855 & 40.18 & 29.10 & 7.5 & 7.5 & 5.8 & 7.5 & 6.5 & 50.13 \\
\hline & $1900, \quad 5.5$ & 11.04 .1855 & 40.20 & 29.10 & 6.7 & $a$ & 5.8 & 6.5 & 5.8 & 43.57 \\
\hline & & 15.04 .1905 & 40.20 & 29.00 & 6.5 & 6.5 & 5.8 & 5.8 & 7.0 & 15.89 \\
\hline & & 13.11 .1948 & 40.23 & 29.02 & 5.6 & 5.8 & 6.5 & 7.5 & 6.5 & 50.13 \\
\hline & & 03.06 .1953 & 40.28 & 28.53 & 5.5 & $a$ & 6.5 & 6.5 & 7.0 & 59.47 \\
\hline & & 06.10 .1964 & 40.24 & 28.16 & 5.6 & $f$ & 7.0 & 7.5 & 7.0 & 109.60 \\
\hline & & 06.10 .1964 & 40.30 & 28.23 & 7.0 & 7.0 & & & & \\
\hline \multirow{14}{*}{8 Bolu } & $968,7.0$ & 25.06 .1910 & 41.00 & 34.00 & 6.5 & 6.5 & 5.5 & 6.5 & 5.7 & 9.04 \\
\hline & $1900, \quad 5.5$ & 09.08 .1918 & 40.89 & 33.41 & 5.8 & $a$ & 5.5 & 5.7 & 5.5 & 17.44 \\
\hline & & 09.06.1919 & 41.16 & 33.20 & 5.7 & 5.7 & 5.5 & 5.5 & 7.5 & 7.02 \\
\hline & & 18.11 .1936 & 41.25 & 33.33 & 5.5 & 5.5 & 5.5 & 7.5 & 5.7 & 33.89 \\
\hline & & 26.11 .1943 & 41.05 & 33.72 & 7.2 & 7.5 & 5.5 & 5.7 & 5.7 & 22.66 \\
\hline & & 01.02 .1944 & 41.41 & 32.69 & 7.2 & $a$ & 5.7 & 6.5 & 5.7 & 9.04 \\
\hline & & 01.02 .1944 & 41.40 & 32.70 & 5.5 & $a$ & 5.7 & 5.7 & 7.5 & 24.46 \\
\hline & & 10.02 .1944 & 41.00 & 32.30 & 5.5 & $a$ & 5.7 & 7.5 & 5.7 & 33.89 \\
\hline & & 02.03 .1945 & 41.20 & 33.40 & 5.6 & $a$ & 5.7 & 5.7 & 5.7 & 22.66 \\
\hline & & 26.10 .1945 & 41.54 & 33.29 & 5.7 & $a$ & 6.5 & 6.5 & 7.5 & 33.41 \\
\hline & & 13.08 .1951 & 40.88 & 32.87 & 6.9 & $a$ & & & & \\
\hline & & 07.09 .1953 & 41.09 & 33.01 & 6.0 & $a$ & & & & \\
\hline & & 05.10 .1977 & 41.02 & 33.57 & 5.7 & 5.7 & & & & \\
\hline & & 06.06.2000 & 40.70 & 32.99 & 5.7 & 5.7 & & & & \\
\hline \multirow[t]{9}{*}{9 Merzifon } & $1598, \quad 7.0$ & 29.08 .1918 & 40.58 & 35.16 & 5.5 & 5.5 & 5.5 & 5.5 & 7.0 & 24.3 \\
\hline & $1900, \quad 5.5$ & 21.11 .1942 & 40.82 & 34.44 & 5.5 & $f$ & 5.5 & 7.0 & 6.1 & 54.21 \\
\hline & & 02.12 .1942 & 41.04 & 34.88 & 5.5 & $f$ & 6.1 & 7.0 & 6.1 & 54.21 \\
\hline & & 11.12.1942 & 40.76 & 34.83 & 5.9 & $f$ & & & & \\
\hline & & 20.12 .1942 & 40.66 & 36.35 & 7.0 & 7.0 & & & & \\
\hline & & 10.12 .1943 & 41.00 & 35.60 & 5.6 & $a$ & & & & \\
\hline & & 30.09 .1944 & 41.11 & 34.87 & 5.5 & $a$ & & & & \\
\hline & & 10.08 .1996 & 40.74 & 35.29 & 5.6 & $f$ & & & & \\
\hline & & 10.03 .1997 & 40.78 & 35.44 & 6.0 & 6.1 & & & & \\
\hline \multirow[t]{7}{*}{10 Tokat } & $127, \quad 7.0$ & 28.05 .1914 & 39.84 & 35.80 & 5.5 & $f$ & 6.3 & 7.1 & 6.3 & 24.84 \\
\hline & $1900, \quad 5.5$ & 24.01 .1916 & 40.27 & 36.83 & 7.1 & 7.1 & & & & \\
\hline & & 29.04 .1923 & 40.07 & 36.43 & 5.9 & $a$ & & & & \\
\hline & & 28.12.1939 & 40.47 & 37.00 & 5.7 & $f$ & & & & \\
\hline & & 13.04 .1940 & 40.04 & 35.20 & 5.6 & $f$ & & & & \\
\hline & & 30.07 .1940 & 39.64 & 35.25 & 6.2 & 6.3 & & & & \\
\hline & & 27.01 .1941 & 39.68 & 35.31 & 5.7 & $a$ & & & & \\
\hline \multirow[t]{5}{*}{11 Erzincan } & $1890, \quad 7.0$ & 16.02 .1904 & 40.30 & 38.40 & 5.5 & 5.5 & 5.5 & 5.5 & 6.4 & 5.06 \\
\hline & $1900, \quad 5.5$ & 09.02.1909 & 40.00 & 38.00 & 6.3 & 6.4 & - & 6.4 & 6.3 & 20.27 \\
\hline & & 09.02.1909 & 40.00 & 38.00 & 5.8 & $a$ & - & 6.3 & 7.9 & 10.6 \\
\hline & & 10.02.1909 & 40.00 & 38.00 & 5.7 & $a$ & - & 7.9 & 5.9 & 20.83 \\
\hline & & 05.03 .1909 & 39.70 & 40.50 & 5.5 & $a$ & - & 5.9 & 6.3 & 6.74 \\
\hline
\end{tabular}


Sayll / Eskişehir Technical Univ. J. of Sci. and Tech. A - Appl. Sci. and Eng. 20 (3) - 2019

\begin{tabular}{|c|c|c|c|c|c|c|c|c|c|c|}
\hline \multirow[t]{2}{*}{ Cont.Table 2} & & 18.05.1929 & 40.20 & 37.90 & 6.1 & 6.3 & - & 6.3 & 6.3 & 24.61 \\
\hline & & & & & & & & & & \\
\hline \multirow[t]{2}{*}{12 Karliova } & $1890,7.0$ & 30.05 .1946 & 39.29 & 41.21 & 5.7 & 5.7 & 5.5 & 5.7 & 5.5 & 7.82 \\
\hline & $1900, \quad 5.5$ & $\begin{array}{l}28.03 .1954 \\
12.02 .1962 \\
30.08 .1965 \\
10.03 .1966 \\
19.08 .1966 \\
20.08 .1966 \\
20.08 .1966 \\
20.08 .1966 \\
20.08 .1966 \\
10.09 .1969 \\
27.03 .1982 \\
12.03 .2005 \\
14.03 .2005 \\
23.03 .2005 \\
06.06 .2005 \\
10.12 .2005 \\
25.08 .2007\end{array}$ & $\begin{array}{l}39.03 \\
39.00 \\
39.36 \\
39.20 \\
38.99 \\
39.37 \\
39.42 \\
39.06 \\
39.17 \\
39.25 \\
39.23 \\
39.39 \\
39.35 \\
39.39 \\
39.37 \\
39.38 \\
39.26\end{array}$ & $\begin{array}{l}40.97 \\
41.60 \\
40.79 \\
41.60 \\
41.77 \\
40.89 \\
40.98 \\
40.76 \\
41.56 \\
41.38 \\
41.90 \\
40.85 \\
40.88 \\
40.80 \\
40.92 \\
40.85 \\
41.04\end{array}$ & $\begin{array}{l}5.5 \\
5.5 \\
5.6 \\
5.6 \\
5.5 \\
6.2 \\
6.0 \\
6.1 \\
6.9 \\
5.5 \\
5.5 \\
5.6 \\
5.7 \\
5.6 \\
5.6 \\
5.5 \\
5.5\end{array}$ & $\begin{array}{c}5.5 \\
5.5 \\
f \\
f \\
f \\
f \\
f \\
f \\
7.0 \\
a \\
5.5 \\
f \\
6.1 \\
a \\
a \\
a \\
a\end{array}$ & $\begin{array}{c}- \\
- \\
- \\
- \\
5.7 \\
- \\
6.1\end{array}$ & $\begin{array}{l}5.5 \\
5.5 \\
7.0 \\
5.5 \\
5.7 \\
7.0 \\
7.0\end{array}$ & $\begin{array}{l}5.5 \\
7.0 \\
5.5 \\
6.1 \\
7.0 \\
6.1 \\
6.1\end{array}$ & $\begin{array}{c}7.86 \\
4.52 \\
15.60 \\
23.05 \\
20.30 \\
38.56 \\
38.56\end{array}$ \\
\hline 13 Van & $\begin{array}{ll}1647, & 7.0 \\
1900, & 5.5\end{array}$ & $\begin{array}{l}28.04 .1903 \\
27.01 .1907 \\
27.01 .1913 \\
14.02 .1915 \\
20.11 .1945 \\
25.06 .1988 \\
23.10 .2011 \\
23.10 .2011 \\
23.10 .2011 \\
23.10 .2011 \\
25.10 .2011 \\
08.11 .2011 \\
09.11 .2011 \\
14.11 .2011\end{array}$ & $\begin{array}{l}39.10 \\
39.10 \\
38.38 \\
38.80 \\
38.63 \\
38.50 \\
38.75 \\
38.80 \\
38.82 \\
38.63 \\
38.80 \\
38.73 \\
38.42 \\
38.70\end{array}$ & $\begin{array}{l}42.50 \\
42.50 \\
42.23 \\
42.50 \\
43.33 \\
43.07 \\
43.43 \\
43.26 \\
43.31 \\
43.10 \\
43.48 \\
43.09 \\
43.22 \\
43.07\end{array}$ & $\begin{array}{l}6.3 \\
6.3 \\
5.5 \\
5.6 \\
5.5 \\
5.5 \\
7.4 \\
5.8 \\
5.9 \\
5.8 \\
5.5 \\
5.5 \\
5.5 \\
5.5\end{array}$ & $\begin{array}{c}6.5 \\
a \\
f \\
5.8 \\
5.5 \\
5.5 \\
7.4 \\
a \\
a \\
a \\
a \\
a \\
a \\
a\end{array}$ & $\begin{array}{c}5.5 \\
- \\
- \\
- \\
5.8 \\
- \\
6.5\end{array}$ & $\begin{array}{l}6.5 \\
5.8 \\
5.5 \\
5.5 \\
6.5 \\
5.8 \\
6.5\end{array}$ & $\begin{array}{l}5.8 \\
5.5 \\
5.5 \\
7.4 \\
5.8 \\
7.4 \\
7.4\end{array}$ & $\begin{array}{c}11.78 \\
30.76 \\
42.59 \\
23.32 \\
11.78 \\
96.68 \\
108.48\end{array}$ \\
\hline
\end{tabular}



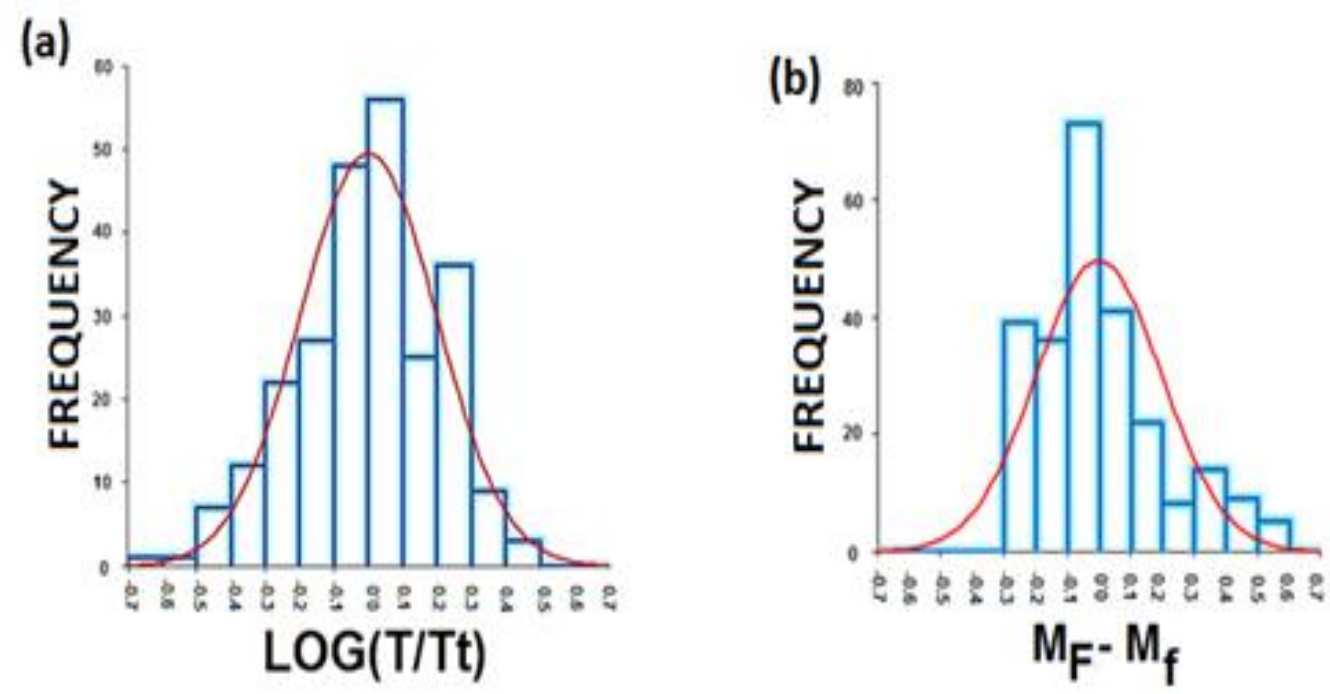

Figure 5 (a) The frequency distribution of $\log \left(T / T_{t}\right)$, (b) The frequency distribution of $M_{F}-M_{f}$.

The frequency distribution of $\log \left(T / T_{t}\right)$, which is compatible with a normal distribution $(\mu=0)$ and standard deviation with $\sigma=0.32$, is shown in Figure 5a. The frequency distribution of the difference between the observed $\left(M_{F}\right)$ and the computed magnitude $\left(M_{f}\right)$ is illustrated in Figure $5 \mathrm{~b}$. This is compatible with a normal distribution $(\mu=0)$ and $\sigma=0.43$. Figure 5a shows that there is a large scattering between the observed $(T)$ and calculated consecutive time interval $\left(T_{t}\right)$. Therefore, it was adopted to determine the probability of an event larger than a $M_{\min }$ (e.g., $M_{\min } \geq 5.5$ for this study) and for a specific time period.

According to $\log \left(T / T_{t}\right)$ in each zone, if there is an earthquake $\left(M_{p}\right)$ occurred in $t$ years before last observation date, the occurrence probability of a main shock $\left(M \geq M_{\min }\right)$ over the next $\Delta t$ years could be determined by the equation (5).

$$
P(\Delta t)=P\left(L _ { 1 } \left\langleZ\left\langle L_{2}\right)=\left[\mathbf{F}\left(\frac{L_{2}}{\sigma}\right)-\mathbf{F}\left(\frac{L_{1}}{\sigma}\right)\right] /\left[1-\mathbf{F}\left(\frac{L_{1}}{\sigma}\right)\right]\right.\right.
$$

Where $L_{1}=\log \left(t / T_{t}\right), L_{2}=\log \left[(t+\Delta t) / T_{t}\right] . \mathbf{F}$ is the cumulative value of the normal distribution $(\mu=$ $0)$ and $\sigma=0.32$.

Table 3 gives the probabilities of occurrence $\left(P_{\Delta t}\right)$ for strong $\left(M_{\min } \geq 6.0\right)$ and large $\left(M_{\min } \geq 7.0\right)$ earthquake within five decades $(\Delta t=10,20, \ldots 50)$ in the 13 seismogenic zones, expected magnitude values $\left(M_{f}\right)$ and the interevent times $\left(T_{t}\right)$. 
Sayll / Eskişehir Technical Univ. J. of Sci. and Tech. A-Appl. Sci. and Eng. 20 (3) - 2019

Table 3. Probabilities of occurrence $\left(P_{\Delta t}\right)$ for strong $\left(M_{\min } \geq 6.0\right)$ and large $\left(M_{\min } \geq 7.0\right)$ earthquake for the next five decades in the 13 seismogenic zones and calculated magnitude values $\left(M_{f}\right)$.

\begin{tabular}{lccccccc}
\hline Seis. Zones & $\mathbf{M}_{\mathbf{f}}$ & $\mathbf{T}_{\mathbf{t}}$ & $\boldsymbol{P}_{\boldsymbol{1 0}}$ & $\boldsymbol{P}_{\mathbf{2 0}}$ & $\boldsymbol{P}_{\boldsymbol{3 0}}$ & $\boldsymbol{P}_{\mathbf{4 0}}$ & $\boldsymbol{P}_{\boldsymbol{5 0}}$ \\
\hline & \multicolumn{8}{c}{$\mathbf{M}_{\mathbf{m i n}} \geq \mathbf{6 . 0}$} \\
\hline 1 Saros Gulf & 6.5 & 40.74 & 0.24 & 0.42 & 0.55 & 0.65 & 0.73 \\
2 Tekirdag & 6.6 & 24.54 & 0.25 & 0.44 & 0.57 & 0.67 & 0.74 \\
3 İstanbul & - & - & - & - & - & - & - \\
4 İzmit & 6.7 & 20.23 & 0.36 & 0.57 & 0.71 & 0.80 & 0.86 \\
5 Düzce & 6.6 & 30.06 & 0.26 & 0.45 & 0.59 & 0.69 & 0.75 \\
6 Bandirma & 6.7 & 16.48 & 0.45 & 0.68 & 0.80 & 0.88 & 0.92 \\
7 Bursa & 6.5 & 40.74 & 0.20 & 0.34 & 0.47 & 0.57 & 0.65 \\
8 Bolu & 6.6 & 25.25 & 0.26 & 0.44 & 0.58 & 0.67 & 0.74 \\
9 Merzifon & 6.6 & 37.24 & 0.22 & 0.41 & 0.56 & 0.67 & 0.75 \\
1 Tokat & 6.5 & 38.78 & 0.23 & 0.40 & 0.52 & 0.62 & 0.70 \\
11 Erzincan & 6.8 & 14.62 & 0.52 & 0.76 & 0.87 & 0.93 & 0.96 \\
12 Karliova & 6.8 & 14.90 & 0.51 & 0.76 & 0.87 & 0.93 & 0.96 \\
13 Van & 6.6 & 24.66 & 0.26 & 0.44 & 0.60 & 0.66 & 0.73 \\
\hline
\end{tabular}

\begin{tabular}{ccccccc}
\hline $\mathbf{M}_{\mathbf{f}}$ & $\mathbf{T}_{\mathbf{t}}$ & $\boldsymbol{P}_{\boldsymbol{1 0}}$ & $\boldsymbol{P}_{\boldsymbol{2 0}}$ & $\boldsymbol{P}_{\boldsymbol{3 0}}$ & $\boldsymbol{P}_{\mathbf{4 0}}$ & $\boldsymbol{P}_{\boldsymbol{5 0}}$ \\
\hline \multicolumn{6}{c}{$\mathbf{M}_{\min } \geq \mathbf{7 . 0}$} \\
\hline 7.3 & 91.20 & 0.12 & 0.20 & 0.30 & 0.36 & 0.44 \\
7.3 & 73.79 & 0.14 & 0.25 & 0.35 & 0.44 & 0.51 \\
7.3 & 76.91 & 0.11 & 0.20 & 0.28 & 0.36 & 0.41 \\
7.3 & 76.03 & 0.06 & 0.14 & 0.24 & 0.33 & 0.41 \\
7.3 & 83.18 & 0.05 & 0.12 & 0.20 & 0.29 & 0.37 \\
7.4 & 59.29 & 0.17 & 0.31 & 0.42 & 0.52 & 0.59 \\
7.3 & 98.85 & 0.09 & 0.17 & 0.26 & 0.33 & 0.40 \\
7.3 & 76.21 & 0.13 & 0.25 & 0.35 & 0.43 & 0.51 \\
7.2 & 107.65 & 0.09 & 0.17 & 0.25 & 0.33 & 0.39 \\
7.2 & 107.30 & 0.10 & 0.18 & 0.26 & 0.33 & 0.40 \\
7.3 & 59.98 & 0.17 & 0.30 & 0.41 & 0.51 & 0.58 \\
7.5 & 43.07 & 0.22 & 0.39 & 0.52 & 0.62 & 0.70 \\
7.3 & 71.29 & 0.01 & 0.07 & 0.16 & 0.26 & 0.35 \\
\hline
\end{tabular}

\section{DISCUSSION}

This study is testing the success of the RTIMAP model and predicts the likelihood probabilities of subsequent events and magnitudes within five decade in the 13 seismogenic zones of NAFZ. The earthquake probabilities in all selected zones have been considerably higher.

The relation with increasing slope between $M_{p}$ and $\log T,(c=0.19)$ and the relation with decreasing slope between $M_{p}$ and $M_{f}(C=-0.14)$ were tried by many researchers $[11,19,24,38-40]$. An increased slope between $M_{p}$ and $\log T$ means that a larger earthquake needs a longer period of repetition. This is due to the fact that the major earthquake reduces the accumulated stress to the lowest level, but the tectonic conditions do not change. A decreasing slope between $M_{p}$ and $M_{f}$ states that there will be small earthquakes after major earthquake or vice versa.

The earthquake probabilities for the next 50 years (2016-2066) in each source yielded significant results. According the Table 3, it is anticipated that a strong event $\left(M_{S} \geq 6.0\right)$ can happen in the seismogenic zone 11 (Erzincan) and 12 (Karliova) with the highest probabilities of $P_{10} \geq 50 \%$ within ten years. The last events have been occurred in January 27, 2003 (Zone 11, $M_{S}=6.2$ ) and in March 14, 2005 (Zone 12) $\left(M_{S}=6.1\right.$, see Table 2). According to the method, $M_{f}=6.8$ and $T_{t} \cong 15$ years were computed for these zones. An earthquake with a magnitude of $M_{S}=5.5$ in Erzincan occurred in 2011. Although this is somewhat smaller than the selected magnitude range $\left(M_{S} \geq 6.0\right)$ in this study, it confirms the values determined for the seismogenic zone 11 .

When the results for large events are examined, it was found that the large event $\left(M_{S} \geq 7.0\right)$ in the next 50 years may most likely $\left(P_{50}=70 \%\right)$ occur in the zone 12 (Karliova). The magnitude and repetition time of the next large event were determined as $M_{f}=7.5$ and $T_{t}=43$ years, respectively. The final event to determine the probability of large event in this zone was occurred in $1966\left(M_{S}=7.0\right)$. This high probability for seismogenic zone 12 also supported the results of other studies for this area [41].

Another high probability for $M_{S} \geq 6.0$ in ten years was found as $P_{10}=45 \%$ for the seismogenic zone 6 (Bandirma). $M_{f}=6.7$ and $T_{t}=17$ years were computed for this zone. The final event to determine the probability was occurred in $1983\left(M_{S}=6.1\right)$. In Table 3 , the second high probability value of $P_{50}=$ $59 \%$ for the large event $\left(M_{S} \geq 7.0\right)$ in the next fifty years was determined for Bandirma. The final event used in the calculation was occurred in $1953\left(M_{S}=7.5\right)$. For this zone, $M_{f}=7.4$ and $T_{t}=59$ years have been determined. [42] was found higher probability for $M_{S} \geq 6.0$ in Bandirma. 
The study of the applicability of the time depended seismicity model for earthquake occurrence in different and same seismogenic zones is important for seismic hazard assessment. It also allows understanding earthquake occurrence in the same and different tectonic conditions. These issues should be further studied in both theory and practice.

\section{REFERENCES}

[1] Cornell CA. Engineering seismic risk analysis. Bull Seism Soc Am 1968; 58: 1583-1606.

[2] Caputo M. Analysis of seismic risk. Nato Advanced Study Institutes Series. Appl Sci 1974; 3, Noordhoff-Leiden.

[3] Shah HC, Movassate M. Seismic risk analysis of California state water project. Proc of Fifth European Conf on Earthq Eng 1975; 2: 156.

[4] Papadopoulos GA, Voidomatis P. Evidence for periodic seismicity in the inner Aegean seismic zone. Pure Appl Geophys 1987; 125: 613-628.

[5] Wesnousky SG, Scholz K, Matsuda T. Integration of geological and seismological data for analysis of seismic hazard: a case study of Japan. Bull Seism Soc Am 1984; 74: 687-708.

[6] Papazachos BC. A time- and magnitude-predictable model for generation of shallow earthquakes in the Aegean Area. Pure Appl Geophys 1992; 138: 2, 287-308.

[7] Stein RS, Barka AA, Dietrich JH. Progressive failure on the north Anatolian fault since 1939 by earthquake stress triggering, Geophys J Intern 1997; 128: 594-604.

[8] Parsons T, Toda S, Stein RS. Heightened odds of large earthquakes near Istanbul: an interaction based probability calculation. Science 2000; 288: 661-665.

[9] Mulargia F, Geller RJ. Earthquake science and seismic risk reduction. Kluwer Dordrecht, 2003.

[10] Coral A. Dependence of earthquake recurrence times and independence of magnitudes on seismicity history, Tectonophysics, 2006; 424: 177-193.

[11] Shanker D, Panthi A, Singh HN. Long-term seismic hazard analysis in Northeast Himalaya and its adjoining regions. Geosci J 2012; 2: 25-32.

[12] Papazachos BC, Papaioannou ChA. Long-term earthquake prediction in the Aegean Area based on a time and magnitude predictable model. Pure Appl Geophys 1993; 140: 4, 593-612.

[13] Mogi K. Earthquake Prediction, Academic Press. University of Tokyo, 1985.

[14] Shanker D. Characteristic studies of tectonics, Seismicity and occurrences of major earthquakes in northeast India. PhD Thesis, Banaras Hindu University 117, 1990.

[15] Shanker D, Singh VP. Regional Time- and Magnitude predictable Seismicity model for north-east India and vicinity. Acta Geod Geophys Hu 1996; 31: 1-2, 181-190.

[16] Shanker D, Singh HN. Application of the time-predictable model in Peninsular India for future seismic hazard assessment. Acta Geophys 2007; 55: 3, 302-312. 
[17] Paudyal H, Singh HN, Shanker D, Singh VP. Validity of Time-Predictable Seismicity Model for Nepal and its Adjoining Regions. J Nepal Geol Soc 2008; 38: 15-22.

[18] Papazachos BC, Karakaisis GF, Scordilis EM. Time dependent seismicity in the continental fracture system. Boll Geof Teor Appl 2014; 55: 3, 617-639.

[19] Papazachos BC, Karakaisis GF, Scordilis EM, Papaioannou ChA. Seismogenic sources in the Aegean area and their predictive properties. Bull Geol Soc Greece 2016; 10.

[20] McKenzie D. Active tectonics of the Mediterranean region. Geophys J Roy Astr Soc 1972; 30: 2, $109-185$.

[21] Barka AA, Kadinsky-Cade K. Strike-slip fault geometry in Turkey and its influence on earthquake activity. Tectonics 1988; 7: 3, 663-684.

[22] Ambraseys NN, Jackson JA. Seismicity of the Sea of Marmara (Turkey) since 1500. Geophys J Int 2000; 141: 3, 1-6.

[23] Barka AA. The North Anatolian fault. Ann Tectonic 1992; 6: 64-195.

[24] Sayil N. Long-term earthquake prediction in western Anatolia with the time- and magnitudepredictable model. Nat Haz 2013; 66: 2, 809-834.

[25] Shebalin NV, Leydecker G, Mokrushina NG, Tatevossian RE, Erteleva OO, Vassilev VYu. Earthquake Catalogue for Central and Southeastern Europe 342BC-1990AD, Final report to contract. ETNU-CT93-0087, 1998.

[26] Burton PW, Xu Y, Qin C, Tselentis GA. A catalogue of seismicity in Greece and the adjacent areas for the twentieth century. Tectonophysics 2004; 390: 117-127.

[27] Bayliss TJ, Burton PW. A new earthquake catalogue for Bulgaria and the conterminous Balkan high hazard region. Nat Hazards Earth Syst Sci 2007; 7: 45-359.

[28] Makropoulos K, Kaviris G, Kouskouna V. An updated and extended earthquake catalogue for Greece and adjacent areas since 1900. Nat Hazards Earth Syst Sci 2012; 12: 1425-1430.

[29] Sayil N. Evaluation of the seismicity for the Marmara region with statistical approaches. Acta Geod Geophys 2014; 49: 265-281.

[30] Al-Tarazia E, Sandvol E. Alternative models of seismic hazard evaluation along the Jordan-Dead Sea transform. Earthq Spectra 2007; 23: 1, 1-19.

[31] Papazachos BC, Papadimitriou EE, Karakaisis GF, Panagiotopoulos DG. Long-term earthquake prediction in the circum-Pacific convergent belt. Pure Appl Geophys 1997; 149: 1, 173-217.

[32] Ambraseys NN. Some characteristic features of the North Anatolian Fault zone. Tectonophysics 1970; 9: 43- 165.

[33] Sengor AMC. The north Anatolian transform fault: Its age offset and tectonic significance. J Geol Soc London 1979; 136: 269-282. 
[34] Molnar P. Earthquake recurrence intervals and plate tectonics. Bull Seism Soc Am 1979; 69: 1, $115-133$.

[35] Gutenberg B, Richter CF. Frequency of Earthquakes in California. Bull Seism Soc Am 1944); 34: $4,185-188$.

[36] Kagan YY, Jackson DD. Long-Term Earthquake Clustering. Geophys J Int 1991; 104: 117-133.

[37] Weisberg S. Applied Linear Regression. Wiley, 1980.

[38] Karakaisis GF. Long-term earthquake prediction along the North and East Anatolian fault zones based on the time and magnitude predictable model. Geophys J Int 1994; 116: 198-204.

[39] Panagiotopoulos DG. Long term earthquake prediction in Central America and Caribbean Sea based on the time and magnitude predictable model. Bull Seism Soc Am 1995; 85: 1190-1201.

[40] Qin C, Papadimitriou EE, Papazachos BC, Karakaisis GF. On the validity of regional time- and magnitude predictable model in Chin. Ann Geofis 1999; 42: 939-956.

[41] Sayil N, Osmansahin I. Investigation of Seismicity of the Eastern Anatolia. Kocaeli 2003 Earthquake Symposium İzmit Turkey 2003; 580-589.

[42] Akol B, Bekler T. Assessment of the statistical earthquake hazard parameters for NW Turkey. Nat Hazards 2013; 68: 2, 837-853. 